НАУКОВО-ТЕОРЕТИЧНИЙ АНАЛІЗ МУЗИЧНО-ПЕДАГОГІЧНОЇ КОНЦЕПЦІЇ З. КОДАЯ

\title{
SCIENTIFIC-THEORETICAL ANALYSIS OF MUSIC-PEDAGOGICAL CONCEPT Z. KODAY
}

Статтю присвячено аналізу музично-педагогічної концепції угорського композитора, музиканта, педагога З. Кодая. З'ясовано, що, усвідомлюючи значну роль музики у вихованні та розвитку особистості, у орормуванні кращих моральних якостей, 3. Кодай намагався вивести музичну освіту на перший план соціокультурного життя країни. Як людина віддана своїй справі, закохана у музику і захоплена нею, він розробив потужну, змістовну, струнку і логічну концепцію музичної освіти.

Представлено характеристику концепціі 3. Кодая, визначено ії основні складники: національний характер музичної освіти, демократизм, доступність змісту навчальної дисципліни для учнів, виховний характер музичної освіти, змістовність навчального матеріалу, обов'язковість навчання музики для кожної людини, урахування вікових та індивідуальних особливостей учнів.

Доведено, що музично-педагогічна концепція 3. Кодая істотно вплинула на розвиток музичної освіти. Вона сприяла створенню єдиної державної системи музичної освіти, широкої системи позашкільного музичного навчання (хори, ансамблі, музично-хорові колективи, гуртки), системи підготовки профессійних педагогів для музичної освіти, популяризації музичної культури серед населення, підвищенню престижності предмету музики в школі, підвищенню рівня музичної культури в суспільстві, формуванню музичного смаку народу.

Показано, що музично-педагогічна концепція 3. Кодая мала змінити не лише систему навчання музики, а й саму структуру освіти в державі, світогляд чілого народу, ієрархію цінностей у суспільстві, оскільки була спрямована на залучення до музичної освіти кожної людини, подолання музичної неграмотності в країні, підвищення престижності предметів музики до статусу обов'язкових i найпотрібніших, застосування в процесі навчання зразків народної пісенної і музичної творчості.
Ключові слова: музична освіта, розвиток особистості, навчання музиці, концепція 3. Кодая.

The article is devoted to the analysis of the musical and pedagogical concept of the Hungarian famous composer, musician, teacher Z. Kodai.

$Z$. Kodai was aware of the significant role of music in the education and development of personality, in the formation of the best moral qualities and tried to bring music education to the forefront of the socio-cultural life of the country. Z. Kodai was a man dedicated to his work, in love with the music he was passionate about. Z. Kodai developed a powerful, meaningful, sophisticated and logical concept for music education. The article describes the characteristics of the concept of $Z$. Kodai, defines its main components: the national character of music education, democracy, accessibility for students, interesting educational material, compulsory music training taking into account the age and individual characteristics of students.

Z. Kodai's music-pedagogical concept significantly influenced the development of music education in the country. The concept promoted the creation of a unified state system of music education, extracurricular music learning systems (choirs, ensembles, bands, musical playgroups), music teacher training system. The concept promoted music to the public. Z. Kodai's concept contributed to raising the level of musical culture in society, forming the musical taste of the people.

Z. Kodai's ideas were to change not only the system of teaching music, but the very structure of education in the state, the outlook of the whole people, the hierarchy of values in society.

As it was aimed at attracting everyone to music education, overcoming musical illiteracy in the country, enhancing the prestige of music subjects to the status of compulsory and necessary, use in the process of teaching samples of folk song and music.

Key words: music education, personality development, music teaching, Z. Kodai concept.

імені Г.С. Сковороди

Постановка проблеми в загальному вигляді. Змістовність, глибина, теоретична ґрунтовність музично-педагогічної концепції 3. Кодая зумовили її популярність і широку зацікавленість спеціалистами усього світу. Водночас діагностується відсутність науково-теоретичного аналізу її змісту, широкого застосування у практиці. Отже, спостерігається певне протиріччя між усесвітнім визнанням цінності концепції 3. Кодая й практично повним її замовчуванням і неопрацьованістю.

Аналіз останніх досліджень і публікацій. Музично-педагогічна спадщина 3. Кодая привертала увагу спеціалістів усього світу і була предметом їхньої спеціальної уваги. Теоретичні ідеї музично-педагогічної концепції 3. Кодая, напрями його діяльності, особливості методики вивчалися
Л. Баренбоймом [1], І. Мартиновим [2], О. Ростовським [3], Е. Тайнель [4; 5], С. Човрій [6].

Виділення не вирішених раніше частин загальної проблеми. Незважаючи на наявність досліджень музично-педагогічної спадщини 3. Кодая, науково-теоретичному аналізу її змісту і педагогічній оцінці їі значення приділяється недостатньо уваги.

Мета статті. На основі вивчення музичнопедагогічної спадщини 3. Кодая проаналізувати його музично-педагогічну концепцію та визначити ії значення для розвитку музичної освіти.

Виклад основного матеріалу. Значення музики для всебічного гармонійного розвитку особистості завжди високо оцінювалося передовою педагогічною громадськістю. Суттєвий 
внесок у розвиток музичної освіти зробив відомий угорський композитор, музикант, музикознавець 3. Кодай. Педагог був переконаний, що музика здатна змінювати людину на краще, а це, своєю чергою, сприятиме перетворенню усього суспільства. Й досягти цього зовсім не складно, потрібно лише оточити кожну людину музикою, яка супроводжуватиме іїі все життя. 3. Кодай разом зі своїми учнями, колегами, педагогами-практиками розробив нову концепцію музичної освіти.

Основні ідеї концепції були представлені в роботах «Музична місія» (1934р.), «Шлях угорської хорової музики» (1935 р.), «Як дати тон» (1937р.), «Музичні ігри» (1937р.), «Музика в дитячому саду» (1941р.), «Про угорське в наших дитячих піснях» (1943р.), «Навіщо потрібні гуртки музичної самоосвіти?» (1944р.), «Музична просвіта» (1945 р.), «Угорське музичне виховання» (1945 р.), «Столітній план» (1947р.) та ін. 3. Кодаєм було також підготовлено багато музично-педагогічного матеріалу для використання під час викладання музики: збірники народних пісень, добірки вправ, які написані відповідно до народних традицій, збірники музичних творів для дітей молодшого віку («Пісні маленьких людей»), література для навчання азам музичної грамоти в дитячому саду, початковій школі («П'ятиступенева музика», «333 вправи для читання»), збірники пісень і підручники для основної школи («Збірник шкільних пісень» у співавторстві з Д. Керені), збірники вправ різного ступеня складності, призначені для використання на всіх етапах музичної освіти (дитячий садок, основна школа, музична академія).

На думку педагога, існуюча система музичної освіти потребувала рефрормування, оскільки не в змозі була вирішити своє основне стратегічне завдання - надати якісні знання з музичної теорії, сорормувати виконавські навички. За спостереженнями 3. Кодая, навіть учні, які мали лише відмінні оцінки, не вміли співати з листа. На думку педагога, навчати систематично музиці треба із самого раннього віку, починаючи з дитячого садочку.

Вивчення й аналіз науково-педагогічного доробку педагога дали змогу виділити основні положення концепції музичної освіти, а саме:

- Національний характер музичної освіти і процесу навчання. Педагог підкреслював, що музична освіта має носити національний характер, здійснюватися рідною мовою. Зміст навчання також рекомендовано наповнювати національним змістом, народною піснею і народною музикою. Для цього було введено до системи музичної освіти аутентичну народну пісню, оскільки раніше народними піснями вважалися і циганські пісні, і німецькі пісні, і різноманітні авторські твори й обробки.

Широко використовувалися ігрові методи у навчанні, переважно дитячі народні ігри.
Національний навчальний матеріал, близький і зрозумілий для дитини, робить процес навчання ефективнім та результативним.

- Змістовність навчального матеріалу, він повинен бути сорормований із найкращих зразків музичного мистецтва.

- Виховний характер музичної освіти. Заняття музикою спрямовані не стільки на формування професійних навичок, скільки на виховання особистості. «Без музики немає цілісної особистості. Можна стати гарним інженером, хіміком і таке інше, навіть якщо і не думати про це до п'ятнадцяти років. Проте навчитися розуміти музику неможливо, якщо в шестирічному віці (а в ігровій фрормі ще раніше) не розпочати регулярно «відкривати», тобто вправляти дитину музиці» [8, с. 8].

- Демократичний характер музичної освіти. Кожна людина має природний музичний інструмент - власний голос, розпочинати навчання музиці треба саме із занять співом, які стануть основою для оволодіння нотною грамотою «Ми повинні вести до музики натовпи» [10, с. 54].

Водночас музична освіта має бути доступною для кожної людини в країні. Педагог відзначав: «Музика не є забавою одинаків, музика - джерело душевних сил, який кожен освічений народ прагне зробити загальним скарбом» [10, с. 97].

- Доступність - навчання музиці не повинно бути складним. Для початку треба навчити дитину ритму, ритмічним основам.

- Обов'язковість музичної грамотності для дітей, молоді. Педагог підкреслював, що знання нотної грамоти, вміння читати ноти мають бути такими ж необхідними, як і вміння читати, писати, рахувати. «Хто не вміє читати музику - $€$ музично безграмотним. Сьогодні, як правило, вважається, що знання нот потрібне тільки тому, хто грає на інструменті, що до музичної освіти шлях лежить лише через навчання грі на інструменті» [10, с. 176-177].

- Урахування вікових та індивідуальних особливостей учнів, їх можливостей, здібностей, здатності до навчання. Необхідно звертати увагу на природні потреби дитини. Особливу увагу педагог звертав на такі інстинктивні, природні прояви дитячої активності, як рух і спів. Кожна дитина виражає свої емоції, настрій саме через рух і спів. Педагог підкреслював, що одна 3 основних проблем сучасних шкіл полягає у тому, що вони не дозволяють дітям достатньо співати і вільно рухатися. «Органічний зв'язок музики і руху: музичні (співочі) ігри під відкритим небом - із давніх часів велика радість у житті дитини» [9, с. 122].

Музично-педагогічна концепція 3. Кодая, яка була прогресивною для угорської музичної педагогіки того часу, оскільки вперше було побудовано струнку, завершену систему навчання музиці, мала велике значення для розвитку музичної освіти, оскільки сприяла: 
1. Створенню єдиної системи музичної освіти на державному рівні. Чіткість, змістовність, методична грамотність концепції дали змогу застосовувати її в будь-яких умовах і на будь-яких ступенях освіти: дошкільної (ясла, дитячі сади), середньої (основні школи, гімназії, спеціальні школи, музичні школи), вищої (консерваторії, музичні академії).

2. Створенню широкої системи позашкільного музичного навчання (хори, ансамблі, музичнохорові колективи, гуртки, так звані гуртки «самоосвіти»).

3. Популяризації музичної культури серед населення.

4. Створенню системи підготовки профресійних педагогів для музичного навчання. «Набагато важливіше, хто є вчителем співу в Кішвардє, ніж хто є директором Опери. Оскільки поганий директор відразу провалиться. Проте поганий вчитель 30 років лет поспіль у 30-ті випусків вбиває любов до музики» [10, с. 55].

5. Підвищенню престижності предмету музики в школі. Навчальна дисципліна «Музика» такий самий важливий предмет, як і будь-який інший. 3. Кодай писав: «Музика сьогодні - «попелюшка» серед інших шкільних предметів» [10, с. 50].

6. Підвищенню рівня музичної культури в суспільстві, фрормуванню музичного смаку народу. У статті «Столітній план» педагог відзначав, що мета його концепції - «угорська музична культура. Засоби: широке розповсюдження музичного читання-письма через школи. I водночас пробудження угорського музичного підходу як у галузі мистецької освіти, так і у вихованні слухачів. Розвиток загальнонаціонального музичного смаку, його постійний прогрес» [8, с. 8].

Зазначимо, що до проблеми формування гарного смаку у музиці 3. Кодай звертався неодноразово. Педагог був переконаний, що поганий смак $€$ наслідком музичної неграмотності, музичної нерозвиненості ще з дитинства. У дорослому віці гарний смак привити складно, майже неможливо. Гарний смак не сорормується сам по собі, над його розвитком треба працювати. Розпочинати цю роботу треба з дитинства: у родині, школі. Засобами розвитку можуть стати різні музичні твори, зразки якісної, «справжньої» музики, які захопили, вразили душу дитини, створили яскраве враження. Педагог уважав, що музика здатна змінювати внутрішній світ людини. «Справа музики - виховання слухачів, тобто виховання суспільства» [8, с. 10].

Усвідомлюючи важливість проблеми фрормування і розвитку вишуканого музичного смаку, педагог визначив умови успішної реалізації цього процесу:

- Заняття музикою з раннього дитинства.

- Розпочинати заняття завданнями активного музикування.
- Поступово, але обов'язково, здійснювати навчання нотній грамоті, фрормувати вміння читати ноти. На думку 3. Кодая, нотна грамотність уможливить для простих людей доступність світової спадщини музичної культури.

Особливу увагу педагог приділяв самій організації процесу навчання музиці у закладах освіти, методиці її викладання. 3. Кодай був переконаний, що основне завдання вчителя музики - зробити процес навчання для дитини привабливим, захоплюючим. «Що робити? Викладати музику в школі так, щоб це не було мукою, а стало насолодою для учня й на все життя привило йому жагу до високої музики» [10, с. 49]. Узагальнюючи основні ідеї 3. Кодая стосовно особливостей викладання музики, можна визначити такі пріоритети:

1. Спиратися на емоції, почуття дитини намагатися побудувати урок у такий спосіб, щоб кожен учень відчув вплив музики, пережив певний емоційний настрій, збагатив свою чуттєву сфреру. «Якщо у найсприятливішому віці між 6 і 16 роками дитина жодного разу не відчує цілющий потік великої музики, то надалі цей потік уже навряд чи подіє на нього. Часто навіть одне враження на все життя відкриває молоде серце для музики. Це враження не можна довіряти випадковості: організовувати його - завдання школи» [10, с. 49].

2. Покласти в основую навчання органічну взаємодію слова, руху та музики. Продовжуючи античну традицію виховання, 3. Кодай усвідомлював важливість фрізичного здоров'я для особистості й пропагував гімнастику, рухову активність задля розвитку фізичної культури. Для розвитку розумової культури рекомендував застосовувати найкращі зразки словесного мистецтва. А головним, основним, найдієвішим засобом виховання «духовної культури» вважав музику. У цьому зв'язку ним було виділено три основні, базові категорії, на яких має відбудовуватися навчання: слово, рух і музика. Задля реалізації цієї ідеї педагогом пропонувалося широке застосування різних музичних ігор, системи ритмічних вправ, розігрування сценок зі зразків народної творчості.

Цікавою є точка зору самого педагога на власну методику. Він зазначав, що його методика полягає у відсутності самої методики. Під час організації занять 3. Кодай дотримувався таких вимог:

а) індивідуальний підхід до особистості учня, урахування його індивідуальних можливостей і здібностей;

б) значущість практичних завдань, вправ активне музикування вважалося важливішим, аніж слухання музики, практичні приклади повинні передувати теорії. Як згадував його учень А. Молнар, «...уроки Кодая складалися 3 двох компонентів: психологічного, зумовленого індивідуальним підходом, і тренувального - великої кількості вправ по грі, письму і музичному аналізу»; 
в) зміст музичного матеріалу для викладання послідовність, велика кількість музичних прикладів [7].

Висновки. Отже, 3. Кодай як людина, віддана своїй справі, закохана у музику і захоплена нею, розробив потужну, змістовну, струнку і логічну концепцію музичної освіти, яка мала змінити не лише систему навчання музиці, а й саму структуру освіти в державі, світогляд та ієрархію цінностей країни. Концепція 3. Кодая була спрямована на залучення до музичної освіти кожної людини, подолання музичної неграмотності в країні, підвищення престижності предметів музики до статусу обов'язкових і найпотрібніших, застосування в процесі навчання зразків народної пісенної і музичної творчості.

На нашу думку, подальшого вивчення заслуговують методика 3. Кодая, реалізація її на практиці та оцінка результатів.

\section{БІБЛІОГРАФІЧНИЙ СПИСОК:}

1. Баренбойм Л.А. Музыкальное воспитание в Венгрии. Москва : Советский композитор, 1983. $400 \mathrm{c}$.
2. Мартынов И.И. Золтан Кодай : монографрия. Москва : Советский композитор, 1983. 250 с.

3. Ростовський О.Я. Теорія і методика музичної освіти : навчально-методичний посібник. Тернопіль : Навчальна книга - Богдан, 2011. 640 с.

4. Тайнель Е. Музичне виховання за методом відносної сольмізації : навчально-методичний посібник. Дрогобич : Коло, 2001. 212 с.

5. Тайнель Е. Теорія та практика загального музичного виховання за методом відносної сольмізації : навчальний посібник. Дрогобич : ЛНУ ім. Івана Франка, 2007. 392 с.

6. Човрій С. Музично-педагогічна концепція Золтана Кодая. Науковий вісник Ужгородського національного університету. 2011. Вип. 23. С. 204-206.

7. Eősze L. Kodály Zoltán, a zeneszerzés tanára. Parlando. 2007. № 6. P. 31-35.

8. Erős Istvánné. Kodály-módszer, Kodálykoncepció, Kodály filozófia. Zenei konferenciák előadásai. Tanulmányi kötet. Szeged: SZTE JGYTFK Ének-zene Tanszék, 2003. P. 8-12.

9. Kiss Á. Magyar gyermekjáték gyújtemény. Budapest, 1891. 568 p.

10. Kodály Z. A zene mindenkié. Budapest: Zeneműkiadó, 1975. 288 p. 